\title{
A Fairness Model Based on Interval Type-2 Fuzzy Set for Islamic Financing Scoring in Indonesia
}

\author{
Galih Kurniawan Sidik ${ }^{*}$, Taufik Djatna ${ }^{2}$ \\ ' Department of Islamic Accounting, Tazkia University College of Islamic Economics, Bogor, \\ Indonesia \\ 2Department of Agricultural Industrial Engineering, Bogor Agricultural University, Indonesia. \\ *Corresponding author. Email: galih@tazkia.ac.id
}

Manuscript submitted August 04, 2014; accepted October 13, 2017.

\begin{abstract}
:
Conventional credit scoring model could lead to serious and unfair problems because in certain case it would incriminate one party in financing. Islamic financing scoring model complies with Sharia rules and ensures fairness among parties. Currently, there are nocertain rules on Islamic financing scoring model which lead to subjective judgments. In the subjective judgments, words could mean different things to different people. Thus, this paper proposed and deployed models for scoring of default risk level by using Interval Type-2 Fuzzy Set model to support the subjective judgments in maintaining Sharia rules. Installment amount and the sum of delay period has used as variables for that scoring. Interval Type-2 Fuzzy Set model was proposed to support the subjectivejudgments in maintaining Sharia rules. Beginning delay period also used as a weight to the risk scoring results. Besides that, this paper also proposed the method for computing real loss value. It has used as a basis for fines computation according to default risk level, bad debt expense, and installment weighted average.
\end{abstract}

Keywords: default risk level; fines computation; interval type-2 fuzzy set; real loss value; Islamic financing scoring.

\section{Introduction}

Credit scoring is a classic problem which is still interesting to study. Fisher's publication in 1936 is known as the first publication that introduces credit scoring system (Lu et al. 2013). Recent years, there are many studies on credit scoring such as Cadeno et al. (2011), Ghodselahi (2011), Huang et al. (2006), Keramati and Yousefi (2011), Leung et al. (2007), Lu et al. (2013), Tsai and Wu (2008), Wu (2011), and Yu et al. (2008). It is interesting to study because of the complexity of processes and data behavior that changes dynamically. The more interesting is most of the scholars only discuss credit scoring as feasibility analysis. Moreover, we can see from existing definitions that tend to equalize credit scoring as a credit feasibility analysis such as in Jentzch (2007), Yu et al. (2008), and Abdou and Pointon (2011).

The conventional credit scoring could lead to serious and unfair problems because in certain case it would incriminate one party in financing. It has seen from several indications: in the scoring of default status based solely on the sum of delay, installments would not be fair because it cannot depict the actual credit risk; while in fines computation, there is no rule of the maximum fines allowed. Under certain conditions, this method can inflict a financial loss on the customer. 
Islamic credit scoring (Islamic financing scoring) model complies Sharia rules and ensures fairness among parties. Several criteria have met to ensure that the proposed method produces fairness and agree with Sharia rules: In scoring of default status, the model and the parameters that used to generate the output should depict the actual credit (financing) risk; and in fines computation. The model and the parameters that used to generate the fines value, should not intend to inflict a financial loss on the customer, fair by their impacts (equal to the real loss value).

If we observe rules or norms in Quran, hadiths, and other laws. Many of them give the certain rules (crisp) such as zakah mal calculation which has calculated by $2.5 \%$ of total assets, and the others just give normative rules that will cause many interpretations and uncertainty such as rules about fines (ta'zir in Islam). There are no certain rules from verses and hadiths that mention the crisp amount of fines.

It is in line with the consensus of "ulama that fines calculation should rely on the real loss value. This rule is still normative and of course will cause many interpretations, uncertainty, and subjective judgments. We know that in subjective judgments, words could mean different things to different people (Wu and Mendel 2009; Liu and Mendel 2008). Consequently, we need a method that can resolve this problem.

Fuzzy logic is known as universal approximates. Thus, there are many applications use fuzzy logic to solve the problem in many areas such as control system and design (Cao et al. 2011; Sahraie et al. 2011), and recommendation system (Wu and Mendel 2009). In type-1 fuzzy sets, the membership function (MF) is a crisp value. According to Mendel et al. (2006), that will be a weakness if the problem has many uncertainties. Unlike type-1 fuzzy sets, type-2 fuzzy sets (T2FS) use fuzzy value in MF computation so that will accommodate the problems that have many uncertainties (WU and Mendel 2009). It makes T2FS more promising to get better performance than type-1 fuzzy (Mendel et al. 2006). One of T2FS that have a lot of implementation in many areas is interval type-2 fuzzy sets (IT2FS). It is because IT2FS has less complexity than the other T2FS. By those advantages, we believe IT2FS can support the subjective judgments for maintaining Sharia rules in financing scoring.

Thus, our research is aimed to develop a fair scheme and algorithm for Islamic financing scoring in default status and fines computation by using IT2FS model. Islamic financing schema which has discussed in this research is Murabaha schema (see the definition in Antonio (2001) and Zuhaili (2011)) because till now that schema still dominates the portfolio of financing of Islamic bank in Indonesia and even in the world (BI 2012).

The rest of this paper has organized as follows: Section 2 presents our proposed method in the scoring of default status, IT2FS model in scoring for default status, and fines computation. Section 3 presents the trial results and discussion. Section 4 concludes.

\section{Methods}

In according to meet the fairness condition, we will explain the steps and the methods which have used in this research.

2.1 Research Workflow

This research workflow was designed to ensure the validity of the proposed model by modifying prototyping techniques (see the detail of prototyping techniques in Laudon and Laudon (2012)). Research workflow has seen in Fig. 1. 


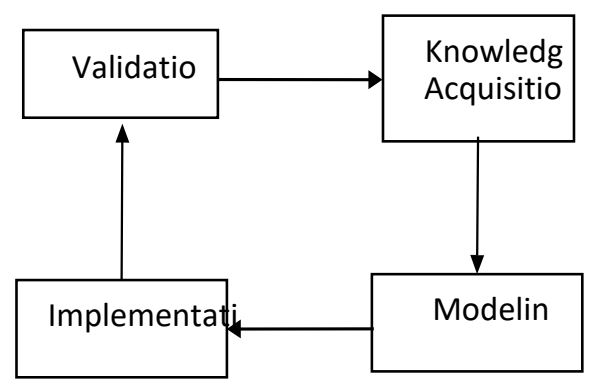

Fig. 1 Research Workflow

This research workflow model was an iteration process, started from knowledge acquisition stage, modeling stage, implementation stage, and validation stage. Knowledge acquisition has conducted by studying the literature of laws and Islamic rules, and interviewing experts to obtain the knowledge needed such as the business process of islamic financing scoring, membership function, and rule base of IT2FS. Modeling stage was conducted to build the models by transforming knowledge that had been gained to be IT2FS models. Implementation stage was conducted to deploy the program application. Validation stage has conducted by asking experts to review and ensure the validity of the models and program application built.

\subsection{Scoring for Default Status}

According to our explanation in introduction part, scoring for default status is aimed to classify the customers (debtor) based on their risk (credit). The existing process is only according to the sum of late day. Therefore in case of fairness guarantee, we propose two parameters for scoring default status that has based on the sum of late day and installment value which are expected more illustrate the credit risk for each customer rather than just based on the sum of late day.

In this research, default status (default) has calculated by using an IT2FS algorithm based on the sum of the late day (late) and installment value (amount) for each customer-i (see equation (1)). Detail computations of the IT2FS algorithm can be seen in Mendel et al. (2006), Wu and Mendel (2009), and Liu and Mendel (2008).

We design the default status value as interval value $[0,100]$. Lower credit risk has characterized by the closer value to zero $(0)$ and vice versa.

In fact, Islamic bank use annuity method for calculating margin (MUI 2012; BI 2013). This treatment will affect the recognition of margin and principal. On annuity method, installment amount for each period will be constant, while margin value has calculated by the remainder of the principal amount (MUI 2012). This treatment will cause the margin value on period- $t$ is higher than period $t+1$, while principal value on period-t is smaller than period $t+1$. This condition will cause the default risk level of financing in Islamic bank is higher on the beginning periods of contract than the end periods of contract. Thus, this research also uses the period as the weight of the scoring result (default). This weight can be obtained by equation (2): 


$$
\frac{P t-N \quad t t}{N}
$$

(2)

On the equation above, $P t$ is the weighted period, $t$ is a current period (calculation period), while $N$ is a total period of the contract. So that, risk level (risk) will be obtained by this formula:

$$
\text { Risk _ default *PTI }
$$

\subsection{IT2FS Model in Scoring for Default Status}

Fuzzification is done to convert the crisp input to be fuzzy input. We assume that the model used in this process is trapezoid model. MF at each variable has converted by three ordinal scales, and according to IT2FS rules, MF for each variable has LMF and UMF; where LMF is characterized by underline, while UMF is characterized by over line (see Table 1).

Table 1 MF IT2FS in scoring default

\begin{tabular}{l|l}
\hline Variable & Linguistic Values \\
\hline late & short, medium, long \\
\hline$\underline{\text { late }}$ & short, medium, long \\
\hline amount & small, medium, big \\
\hline$\underline{\text { amount }}$ & small, medium, big \\
\hline default & low, medium, high \\
\hline default & low, medium, high \\
\hline
\end{tabular}

In the MF calculation, late day MF in day unit (see equation (4), (5), (6), (7), (8), and (9)), instalment MF in rupiah unit (see equation (10), (11), (12), (13), (14), and (15)), while default status MF in percentage unit (\%) (See Table 2).

Table 2 MF Default Status

\begin{tabular}{c|c|c}
\hline Default & score & score \\
\cline { 2 - 2 } & & \\
\hline Low & 0 & 40 \\
\hline Middle & 30 & 70 \\
\hline High & 60 & 100 \\
\hline
\end{tabular}


The rules have been seeing in Table 3.

Table 3 Rule base Model IT2FS

\begin{tabular}{c|c|c|c|c|c|l}
\hline No & & Late & & Install & & Status default \\
\hline $\mathbf{1}$ & IF & Short & AND & Small & THEN & Low \\
\hline $\mathbf{2}$ & IF & Short & AND & Middle & THEN & Low \\
\hline $\mathbf{3}$ & IF & Short & AND & Big & THEN & Middle \\
\hline $\mathbf{4}$ & IF & Middle & AND & Small & THEN & Low \\
\hline $\mathbf{5}$ & IF & Middle & AND & Middle & THEN & Middle \\
\hline $\mathbf{6}$ & IF & Middle & AND & Big & THEN & High \\
\hline $\mathbf{7}$ & IF & Long & AND & Small & THEN & Middle \\
\hline $\mathbf{8}$ & IF & Long & AND & Middle & THEN & High \\
\hline $\mathbf{9}$ & IF & Long & AND & Big & THEN & High \\
\hline
\end{tabular}

Based on our models, the final output (default - $y$ ) will produce the interval value [0, 100] that will be used in fines computation

\section{Result and Discussion}

The series of the evaluation conducted by using proposed method to compute the risk of default value and fines amount. The dataset was a hypothetical data from two customers who have different values of installments, i.e., customers who have installment value of 1 million and 3.8 million. The data were computed for each end of month period of delay for 0 days to 12 months. This evaluation assumed that both of customer had been arrears since June 30th, 2013 until May 31st, 2014. In case of fines computation, this evaluation assumed that bad debt expense value was $20 \%$ to total installment. Thus, bad debt expense value was 960 thousand rupiahs (20 \%*(1 million + 3.8 million) rupiahs). Evaluation results can be seen in Fig. 2 and Fig. 3.

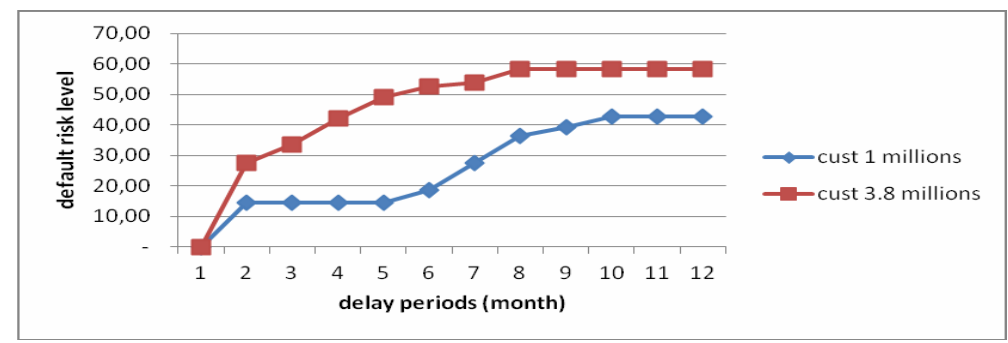

Fig. 2 Evaluation results of default risk level computation

Fig. 2 show that default risk level will be in line with the sum of the delay period, high delay period will cause high default risk level. But, because this research model has developed by adopting rules of Bank of Indonesia number 14/15/PBI/2012 that have limited by 270 days ( 9 months), thus the maximum default risk level would be obtained if the customer had been arrears in 270 days. For next periods (delay periods of $\geq 270$ days ( 9 months)), the default risk level would be constant. 


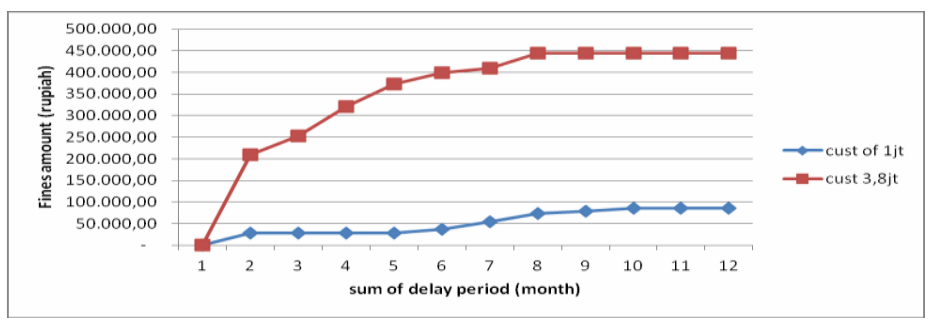

Fig. 3 Evaluation results of fines computation

The result of default risk level was used to compute fines amount by using equation (25). Evaluation results have been seeing in Fig. 3. According to our explanation in introduction part, in the conventional method, the fines amount will continue to increase with the sum of delay periods without any maximum limit. While the proposed method (see Fig. 4), the fines amount will achieve the maximum value in a delay period of 9 months, so that the next period will be constant. Based on these results, we claim that our methods are fair and compliance with sharia.

\section{Conclusion}

This paper proposed models for scoring of default risk level. Installment amount and the sum of delay period have used as variables for that scoring. Interval Type-2 Fuzzy Set model was proposed to support the subjective judgments in maintaining Islamic rules. Beginning delay period also used as weight to the risk scoring results. Besides that, this paper also proposed the method for computing real loss value. It was used as a basis in fines computation according to default risk level, bad debt expense, and installment weighted average. It has shown that our proposed method is fair and compliance with Sharia.

\section{Acknowledgment}

This paper has been presented at International Conference on Islamic Economics and Finance (ICIEF) 2015.

\section{References}

[1] Abdou H A, Pointon J. 2011. Credit scoring, statistical techniques, and evaluation criteria: A Review of the Literature. Intelligent Systems in Accounting, Finance, and Management 18, hal 59-88 (2011) DOI: 10.1002/isaf.325.

[2] Antonio MS. 2001. Bank Syariah dari teori ke praktek. Jakarta (ID): Gema Insani Pr. [BI] Bank Indonesia. 2012. Peraturan Bank Indonesia nomor 14/15/PBI/2012 tentang kualitas aset Bank Umum. Jakarta (ID). (Islamic Bank, From Theory to Practice)

[3] [BI] Bank Indonesia. 2013. Surat Edaran Bank Indonesia nomor 15/26/DPbS perihal Pelaksanaan Pedoman Akuntansi Perbankan Syariah Indonesia. Jakarta (ID). (Circular Letter of Bank Indonesia no. 15/26/DPbS Regarding the Implementation of Accounting Guidelines for Indonesia Islamic Banking.

[4] Cadeno, AM, Marin DBA, Trillo JA. 2011 . Artificial metaplasticity neural network applied to credit scoring. International Journal of Neural Systems, Vol 21, No 4 (2011) hal 1-7. DOl: 


\section{$10.1142 / \mathrm{S0129065711002857.}$}

[5] Ghodselahi, A. 2011. A hybrid support vector machine ensemble model for credit scoring. International Journal of Computer Application vol. 17 No 5 March 2011.

[6] Hamadani AZ, Shalbafzadeh A, Rezvan T, Moghadam A. 2013. An integrated genetic-based model of naive bayes networks for credit scoring. International Journal of Artificial Intelligence

\& Application (IJAIA) Vol. 4, No. 1, January 2013, doi:10.5121/ijaia.2013.4107.

[7] Huang CL, Chen MC, Wang CJ. 2007. Credit scoring with a data mining approach based on support vector machine. Expert systems with applications (2006) doi: 10.1016/j.eswa.2006.07.007.

[8] Laudon, Kenneth C, Laudon, Jane P. 2012. Management Information System, Managing the Digital Firms 12th Ed. New Jersey (USA): Pearson Prentice Hall.

[9] LU H, Liyan H, Hongwei Z. 2013. Credit scoring model is hybridizing artificial intelligence with logistic regression. Journal of Networks, Vol. 8, No. 1, January 2013, doi: 10.4304/jnw.8.1.253-261.

[10] Jentzsch, N. 2007. Financial privacy: an international comparison of credit reporting systems (contributions to economics). Springer.

[11] Keramati A, Yousefi N. 2011. A proposed classification of data mining techniques in credit scoring. Proceedings of the 2011 International Conference on Industrial Engineering and Operations Management Kuala Lumpur, Malaysia, January 22-24, 2011

[12] Leung K, France C, and Christopher C. 2007. Consumer credit scoring using an artificial immune system algorithm. IEEE Congress on Evolutionary Computation 2007.

[13] Liu F, Mendel JM. 2008. Encoding words into interval type-2 fuzzy sets using an interval approach. IEEE Transaction on Fuzzy Systems, Vol. 16, No. 6, December 2008, doi: 10.1109/TFUZZ.2008.2005002

[14] Mendel JM, John RI, Liu F. 2006. Interval type-2 fuzzy logic systems made simple. IEEE Transaction on Fuzzy Systems, Vol. 14, No. 6, December 2006, doi:10.1109/TFUZZ.2006.879986.

[15] [MUI] Majelis Ulama Indonesia. 2000. Fatwa Dewan Syariah Nasional-Majelis Ulama Indonesia nomor 17/DSN-MUI/2000 tentang sanksi atas nasabah mampu yang menunda pembayaran. Jakarta (ID). (Fatwa of the National Islamic Council- Majelis Ulama Indonesia no. 17/DSNMUI/2000 on Sanctions on Capable Customers Who Delay Payments)

[16] [MUI] Majelis Ulama Indonesia. 2012. Fatwa Dewan Syariah Nasional-Majelis Ulama Indonesia nomor 84/DSN-MUI/XII/2012 tentang metode pengakuan keuntungan AlTamwil Bi AlMurabahah (Pembiayaan Murabahah) di Lembaga Keuangan Syariah. Jakarta (ID). (Fatwa of the National Islamic Council- Majelis Ulama Indonesia no. 84/DSN-MUI/XII/2012 concering the Method of Recognizing the Profit of $\mathrm{Al}$ Tamwil Bi Al-Murabahah (Murabahah Fianncing) in Islamic Financial Constitution, Jakarta)

[17] Tsai, Cf, Wu JW. 2008. Using neural network ensembles for bankruptcy prediction and credit scoring. Expert systems with applications. Vol. 34. hal. 2639-2649.

[18] Wu D, Mendel JM. 2009. A comparative study of ranking methods, similarity measures and uncertainty measures for interval type-2 fuzzy sets. Information Sciences 179 (2009) 1169-1192, Elsevier Inc., doi: 10.1016/j.ins.2008.12.010.

[19] Wu, WW. 2011. Improving classification accuracy and causal knowledge for better credit decisions. International Journal of Neural Systems, Vol 21, No 4 (2011) hal 297-309. DOI: $10.1142 /$ S0129065711002845.

[20] YU L, Wang S, Lai KK, Zhou L. 2008. Bio-inspired credit risk analysis: computational intelligence with support vector machines. Springer. 
[21] Zuhaili W. 2011. Fiqih Islam waadillatuhu Jilid 5. Abdul Hayyie al-Kattani dkk. Darul Fikr, Jakarta (ID): Gema Insani Pr. Translated from: Fiqhul Islam wa Adillatuhu Juz IV. 10th Edition. (Islamic Jurisprudence) 